\title{
Dipeptide (Methionyl-Methionine) Transport and Its Effect on $\beta$-Casein Synthesis in Bovine Mammary Epithelial Cells
}

\author{
Caihong Wang ${ }^{a}$ Fengqi Zhao a,b Jianxin Liu ${ }^{a}$ Hongyun Liu \\ aCollege of Animal Sciences, Zhejiang University, Hangzhou, China, bLaboratory of Lactation and \\ Metabolic Physiology, Department of Animal and Veterinary Sciences, University of Vermont, \\ Burlington, USA
}

\section{Key Words}

Bovine mammary epithelial cell $-\beta$-casein synthesis - Dipeptide - Methionyl-methionine • mTOR signaling pathway $\bullet$ Peptide transporter 2

\begin{abstract}
Background/Aims: The aim of this study was to investigate the transport properties and utilization of methionyl-methionine dipeptide (Met-Met) in $\beta$-casein $(\beta-C N)$ synthesis in bovine mammary epithelial cells (BMECs). Methods: The transport properties were studied for the effects of time, $\mathrm{pH}$, concentration, temperature and inhibitors using Met-Met-FITC in BMECs. BMECs were treated with different concentrations of Met-Met $(0,20,40,80,120$ and $160 \mu \mathrm{g} / \mathrm{ml}$ ). In several experiments, the cells were treated with Janus kinase 2 (JAK2) inhibitor (tyrphostin AG-490, $50 \mu \mathrm{M}$ ) and mammalian target of rapamycin (mTOR) inhibitor (rapamycin, $100 \mathrm{ng} / \mathrm{ml}$ ). Results: The uptake of Met-Met-FITC by BMECs was rapid during the first fifteen minutes and became saturated after 15 minutes. The transport of Met-Met-FITC in BMECs exhibited a Michaelis constant of $52.4 \mu \mathrm{M}$ and maximum transport velocity of $14.8 \mathrm{pmol} /$ $\mathrm{min} / \mathrm{mg}$ protein. The uptake of Met-Met-FITC in BMECs was $\mathrm{pH}$-dependent, peaked at $\mathrm{pH} 6.5$ and was significantly inhibited by other peptides, including Met-Lys, Lys-Lys, Gly-Met, Gly-Leu and Met-Leu. Knocking down the peptide transporter 2 (PepT2) with small interference RNA markedly decreased Met-Met-FITC uptake. Met-Met concentration-dependently increased the PepT2 expression and $\beta-C N$ synthesis in BMECs with an optimal concentration of $80 \mu \mathrm{g} / \mathrm{ml}$. At $80 \mu \mathrm{g} / \mathrm{ml}$, Met-Met also enhanced the cell viability and cyclin D1 expression and promoted cell cycle transition from $\mathrm{G} 1$ phase to $S$ phase. In addition, $80 \mu \mathrm{g} / \mathrm{ml}$ Met-Met increased the mRNA abundance of JAK2 and signal transducer and activator of transcription 5 (STAT5) and enhanced the phosphorylation of JAK2, STAT5, mTOR, p70 ribosomal S6 kinase 1 and eukaryotic initiation factor $4 \mathrm{E}$ binding protein 1 . The inhibition of JAK2 and mTOR significantly decreased Met-Met-induced increase in cell viability and $\beta-C N$ synthesis in BMECs. Conclusion: Our data
\end{abstract}


elucidated the properties of peptide transporter and its effect on $\beta-C N$ synthesis in BMECs. Met-Met, taken up by PepT2, enhances cell proliferation and promotes $\beta-\mathrm{CN}$ synthesis by activating JAK2-STAT5 and mTOR signaling pathways in BMECs.

\section{Introduction}

(C) 2018 The Author(s)

Published by S. Karger AG, Basel

The bovine mammary gland requires large amounts of nutrients for milk protein synthesis during lactation. Studies have determined that blood supply of several essential amino acids cannot account for the demand of milk protein synthesis [1,2]. For example, Mabjeesh et al. (2002) observed that mammary uptake of free Met, His and Pro was lower than their output in milk protein synthesis in goats [3]. It is well-known that there are large amounts of peptides circulating in the blood [4]. Multiple studies have observed that the peptide-bound amino acid (PBAA) in the blood plasma can make up for the deficiencies of the essential amino acids for milk protein synthesis [5-7]. Research has demonstrated that bovine mammary epithelial cells (BMECs) can utilize methionine-containing peptides to support protein accretion [5]. Our previous study also observed that methionine-containing dipeptide is more effective in promoting milk protein synthesis than free methionine, and replacement of $15 \%$ methionine (Met) with methionyl-methionine (Met-Met) is the most efficient to enhance milk protein synthesis [7].

Peptide utilization by mammary tissue is influenced by blood concentration and intracellular metabolism of small peptides as well as transport of small peptides into mammary cells. Uptake of small peptides by the cells is mediated by peptide transporters located on the plasma membrane of different epithelial cells [8]. Four peptide transporters, including peptide transporter 1 (PepT1), peptide transporter 2 (PepT2), peptide histidine transporter 1 (PhT1), and peptide histidine transporter 2 (PhT2) have been identified in mammalian cells [8-11]. PepT2 is predominantly expressed in the kidney and mammary gland $[9,10]$. Our study has verified that PepT2 was expressed in bovine mammary gland and inhibition of PepT2 caused a decrease of Met-Met-stimulated milk protein synthesis, which indicated that PepT2 may function in Met-Met absorption in bovine mammary gland [7]. However, the transport kinetics of PepT2 in BMECs remains unknown.

The Janus kinase 2 (JAK2)-signal transducer and activator of transcription 5 (STAT5) and mammalian target of rapamycin (mTOR) signaling pathways regulate cell growth and protein synthesis $[7,12,13]$. The latest reports revealed that AA and PBAA are key activators of JAK2-STAT5 and mTOR signaling pathways $[7,13]$. Several AAs and PBAAs can modify the expression of downstream targets of mTOR signaling pathway to modulate milk protein translation [7, 14]. However, few studies have examined the effect of Met-Met on the activation of JAK2-STAT5 and mTOR signaling pathways in BMECs.

In this study, we investigated the properties of peptide transporter for Met-Met and the effects of Met-Met uptake on expression of $\beta$-casein $(\beta-\mathrm{CN})$ and cell proliferation as well as the regulation mechanisms of Met-Met on milk protein synthesis in BMECs.

\section{Materials and Methods}

Isolation, culture and treatment of BMECs

Mammary gland tissues were obtained from mid-lactation Holstein dairy cows at a local abattoir. The use of animal tissues was approved by the Institutional Animal Use Committee of Zhejiang University. Preparation and culture of primary BMECs were followed our previously established procedures [15-17]. Briefly, the mammary gland tissues were put into DMEM/F12 medium (Invitrogen, Carlsbad, California, USA) containing 10\% fetal bovine serum (FBS, Gibco, Scoresby, Victoria, Australia) and 1\% penicillin and streptomycin (Sangon Biotech, Shanghai, China) and taken back to the lab. The mammary gland tissues were washed several times with PBS until the solution was pellucid, and it was later cut into $1 \mathrm{~mm}^{3}$. The small pieces of mammary gland tissue were digested in an Erlenmeyer flask containing $20 \mathrm{ml}$ of $0.25 \%$ trypsin 


\section{Cellular Physiology Cell Physiol Biochem 2018:49:479-488 \begin{tabular}{l|l|l} 
and Biochemistry.1159/000492987 & $\begin{array}{l}\text { (C) } 2018 \text { The Author(s). Published by S. Karger AG, Basel } \\
\text { www.karger.com/cpb }\end{array}$
\end{tabular}}

Wang et al.: Dipeptide Transport and Its Effect on $\beta$-Casein Synthesis

(Amesco, Solon, Ohio, USA) in PBS solution for $30 \mathrm{~min}$ in an air bath shaker at $37^{\circ} \mathrm{C}$. The supernatant was discarded, and the tissues were digested with $6 \mathrm{ml}$ of collagenase I (Sigma, St. Louis, Missouri, USA) and collagenase II (Sigma) in PBS solution for $4 \mathrm{~h}$ in an air bath shaker at $37^{\circ} \mathrm{C}$. Trypsinization was terminated with $1 \mathrm{ml}$ DMEM/F12 containing 10\% FBS. The digested tissue solution was filtered with eight layers of gauze and later filtered with a 400-mesh filter. The filtrate was centrifuged at $1000 \mathrm{rpm}$ for $5 \mathrm{~min}$, and the dispersed cells were seeded in plastic dishes. The dishes were incubated at $37^{\circ} \mathrm{C}$ in a humidified atmosphere containing $5 \% \mathrm{CO}_{2}$. After the bottoms of the dishes were filled with cells, BMECs and fibroblasts were separated based on their different sensitivity to $0.25 \%$ trypsin and $0.02 \%$ EDTA. The purified cells were seeded in flasks in complete medium containing DMEM/F12 with 10\% FBS, $5 \mathrm{mg} / \mathrm{ml}$ transferrin (Sigma), $5 \mathrm{mg} / \mathrm{ml}$ insulin (Sigma), $5 \mathrm{mg} / \mathrm{ml}$ prolactin (Sigma), $1 \mathrm{mg} / \mathrm{ml}$ hydrocortisone (Sigma), $10 \mathrm{ng} / \mathrm{ml}$ epithelial growth factor (Sigma), and 1\% glutamine (Sigma). BMECs used in this study were between passages 5 and 8.

\section{PepT2 siRNA transient transfection}

After the cells reached $70 \%$ confluence, siRNA transfection was performed using lipofectamine RNAiMAX reagent (Invitrogen, Carlsbad, California, USA) according to the manufacturer's protocol. Briefly, each sequence of small interference RNA ( $60 \mathrm{pmol})$ and $9 \mu$ l Lipofectamine RNAiMAX reagent were diluted into $150 \mu \mathrm{l}$ opti-MEM medium (Invitrogen, Scoresby, Victoria, Australia) and mixed for $5 \mathrm{~min}$. The mixture was added to BMECs for $6 \mathrm{~h}$, and the cells were then incubated with complete medium for $24 \mathrm{~h}$. The sequences for PepT2 small interference RNA (Genepharma, Shanghai, China) were sense, CCCUGUAUUUCCUGUAUUUTT, and anti-sense, AAAUACAGGAAAUACAGGGTT. The sequences for the negative control (NC) were sense, UUCUCCGAACGUGUCACGUTT, and anti-sense, ACGUGACACGUUCGGAGAATT.

\section{Uptake of Met-Met}

The uptake study was performed according to the methods of a previous study [18]. Cells were seeded in a 12-well plate for $48 \mathrm{~h}$. For the Met-Met uptake experiments, the cells were washed with prewarmed Krebs-Ringer Modified Buffer (KRB) three times and preincubated for 30 min with prewarmed medium at $37^{\circ} \mathrm{C}$. The $\mathrm{KRB}$ was aspirated, and the cells were later incubated with $\mathrm{KRB}$ containing 25, 50, 75, 100 or $150 \mu \mathrm{M}$ Met-Met-FITC (Sangon) for $10 \mathrm{~min}$ at $37^{\circ} \mathrm{C}$ at $\mathrm{pH} 7.4$ in a kinetic analysis. To study the time and $\mathrm{pH}$ effects, the uptake of $25 \mu \mathrm{M}$ of Met-Met-FITC was measured at 5, 10, 15, 30 and $45 \mathrm{~min}$ and under various $\mathrm{pH}$ conditions $(5.5,6.0,6.5,7.5$, and 8.0). For the inhibition studies, the uptake of Met-Met-FITC was measured in the presence of $5 \mathrm{mM}$ of various dipeptides (Met-Lys, Lys-Lys, Gly-Met, Gly-Leu, and Met-Leu) at pH 7.4 for $10 \mathrm{~min}$. For the temperature effects, the BMECs were incubated with KRB containing $25 \mu \mathrm{M}$ of MetMet-FITC at $37^{\circ} \mathrm{C}$ or at $4^{\circ} \mathrm{C}$ at pH 7.4 for 10 min. To study the effects of PepT2 on Met-Met-FITC uptake, the uptake of $25 \mu \mathrm{M}$ Met-Met-FITC was studied in BMECs transfected with either the control or PepT2 small interference RNA described above at pH 7.4 for $10 \mathrm{~min}$. The uptake studies were terminated by washing the cells three times with ice cold KRB. The cells in the plate were lysed with $1 \%$ Triton X-100 and analyzed with a microplate reader (excitation at $495 \mathrm{~nm}$ and emission at $530 \mathrm{~nm}$ ). The protein content was determined by the BCA method.

\section{Western blot}

BMECs were rinsed three times with ice-cold PBS and lysed in RIPA lysis buffer (Beyotime, Jiangsu, China) with $1 \mathrm{mM}$ phenylmethane sulfonyl fluoride (Beyotime). Cell lysates were centrifuged at 12, $000 \mathrm{~g}$ for $10 \mathrm{~min}$, and the supernatants were collected and measured for the protein concentration with the BCA protein assay kit (Beyotime). Next, $20 \mu \mathrm{g}$ of protein were separated on polyacrylamide gels and transferred to polyvinylidene fluoride (PVDF) microporous membranes. The membranes were blocked with $3 \%$ pig serum albumin in $0.1 \%$ Tween-20 (TBST) for $2 \mathrm{~h}$ at room temperature and then incubated with primary antibodies for $\beta$-CN (1:1000; BGI, Beijing, China), $\beta$-actin (1:1000; Boster, Wuhan, China), PepT2 (1:1000, Abcam, Cambridge, UK), pJAK2 (Tyr 1007), STAT5, pSTAT5 (Tyr 694), mTOR, pmTOR (Ser 2448), S6K1, pS6K1 (Thr 389), 4EBP1, and p4EBP1 (Thr 37/46) (1:1000, Cell Signaling Technology) in blocking buffer at $4^{\circ} \mathrm{C}$ overnight. After washing the samples with TBST three times, the membranes were incubated at room temperature for $2 \mathrm{~h}$ with an HRP-conjugated secondary antibody (1:5000, Boster, Wuhan, China). The membranes were washed with TBST three times and detected with a chemiluminescence system (CLiNX Science Instruments, Shanghai, China). The results were analyzed with ImageJ (NIH, Bethesda, MD, USA). 


\section{Cellular Physiology Cell Physiol Biochem 2018;49:479-488 \begin{tabular}{ll|l} 
DOI: 10.1159/000492987 & $\begin{array}{l}\text { O } 2018 \text { The Author(s). Published by S. Karger AG, Basel } \\
\text { www.karger.com/cpb }\end{array}$ \\
\hline
\end{tabular}}

Wang et al.: Dipeptide Transport and Its Effect on $\beta$-Casein Synthesis

The intensity of the $\beta$-CN and PepT2 bands were normalized to $\beta$-actin. The phosphorylation of JAK2, STAT5, mTOR, S6K1 and 4EBP1 was calculated as the ratio of the relative intensity of the phosphorylated form to the respective total protein.

\section{Cell viability assay}

For cell viability analysis, 5000 cells were seeded in 96-well plates and cultured for $4 \mathrm{~h}$, and the cells were treated with serum starved medium for $12 \mathrm{~h}$ before they were treated with different concentrations of Met-Met $(0,20,40,80,120$ and $160 \mu \mathrm{g} / \mathrm{ml})$ with or without the JAK2 inhibitor (tyrphostin AG-490, 50 $\mu \mathrm{M})$ and mTOR inhibitor rapamycin $(100 \mathrm{ng} / \mathrm{ml})$ for $24 \mathrm{~h}$. Subsequently, cells in each well were treated with $10 \mu \mathrm{l} \mathrm{CCK8}$ and incubated for $2 \mathrm{~h}$, and the absorbance was determined with a microplate reader (Molecular Devices, Sunnyvale, CA, USA) at $450 \mathrm{~nm}$.

\section{Flow cytometry}

BMECs were seeded in 6-well plates and cultured for $24 \mathrm{~h}$. Next, BMECs were starved for $12 \mathrm{~h}$ before they were treated with different dosages of Met-Met dipeptide for $24 \mathrm{~h}$. The cells were washed with PBS and digested with $0.25 \%$ trypsin and $0.02 \%$ EDTA. After that step, the digestion was terminated with DMEM/ F12 with FBS (Gibco), and the cells were collected with centrifugation at $1000 \mathrm{~g}$ for $5 \mathrm{~min}$. The supernatant was discarded, and the cell pellet was fixed with $1 \mathrm{ml} 70 \%$ cold ethanol at $4{ }^{\circ} \mathrm{C}$ for $12 \mathrm{~h}$. Next, the cells were washed with cold PBS and resuspended in $0.5 \mathrm{ml}$ of staining reagent containing Propidium and RNase for 30 min in the dark at $37^{\circ} \mathrm{C}$. Cell cycle analysis were analyzed by flow cytometry (BD 134 FACSCalibur, Franklin Lakes, NJ, USA). Fluorescence was monitored at $488 \mathrm{~nm}$.

\section{Quantitative reverse transcription real-time PCR ( $q R T-P C R)$.}

Total RNA was isolated from BMECs with an RNA isolation kit (Aidlab, Beijing, China) according to the manufacturer's instructions. The cDNA was synthesized from $1 \mathrm{mg}$ RNA with the use of a reverse transcription kit (Takara, Beijing, China). The mRNA abundance of genes was quantified using an ABI 7500 (Applied Biosystems, Singapore) and SYBR PrimeScriptTM reagent kit (Takara) in a reaction volume of $20 \mu \mathrm{L}$. Primers used were as follows: JAK2: forward: TGAAGAAAACAGGTAATCAGACTGGA, reverse: AACATTTTCTCGCTCAACAGCA; STAT5: forward: GCAGCTCCAGAACACGTACG, reverse: CATTGTTGGCTTCTCGGACC [7].

\section{Statistical analysis}

All experiments were performed with three replicates. Data were analyzed using the GLM procedure of SAS software (SAS Institute, Cary, North Carolina, USA). Tukey's multiple range test was used to examine the significance of differences between means. Values are shown as the means \pm SEM. $P<0.05$ was considered to be a significant difference.

\section{Results}

Met-Met dipeptide transport in BMECs

Dipeptide transport was studied using the model peptide Met-Met-FITC in BMECs. The uptake of Met-Met was rapid during the first 15 minutes and gradually became saturated after 15 minutes (Fig. 1A). The optimal pH for Met-Met uptake was 6.5 (Fig. 1B). The uptake of Met-Met was concentration-dependent with a $\mathrm{Km}$ value of $52.4 \mu \mathrm{M}$ and saturated over $120 \mu \mathrm{mol}$ with Vmax of $14.8 \mathrm{pmol} / \mathrm{min} / \mathrm{mg}$ protein (Fig. 1C). The Met-Met uptake was significantly inhibited by other peptide, including Met-Lys, Lys-Lys, Gly-Met, Gly-Leu and Met-Leu (Fig. 1D). In addition, the uptake of Met-Met in BMECs was significantly higher at $37^{\circ} \mathrm{C}$ than at $4^{\circ} \mathrm{C}$ (Fig. 1E). Knocking down the PepT2 significantly decreased the Met-Met uptake in BMECs (Fig. 1F). 
Fig. 1. Transport characteristics of methionylmethionine-FITC (Met-Met-FITC) in bovine mammary epithelial cells (BMECs). (A) Uptake of $25 \mu$ M Met-MetFITC was measured over 45 min in BMECs at pH 7.4. (B) Uptake of Met-Met-FITC was measured after a $10 \mathrm{~min}$ incubation at different $\mathrm{pH}$ values (5.5-8.0). (C) Uptake of Met-Met-FITC was measured with incubation of different concentrations of Met-Met-FITC $(25-150 \mu \mathrm{M})$ at $\mathrm{pH} 7.4$ for $10 \mathrm{~min}$. (D) The BMECs were exposed to $25 \mu \mathrm{M}$ MetMet-FITC in the presence of Met-Lys, Lys-Lys, Gly-Met, Gly-Leu and Met-Leu at pH 7.4 for $10 \mathrm{~min}$, respectively. (E) Met-Met-FITC uptake was measured at $\mathrm{pH} 7.4$ after 10 min incubation at $37{ }^{\circ} \mathrm{C}$ and $4{ }^{\circ} \mathrm{C}$, respectively. (F) Knockdown of PepT2 reduces the uptake of Met-MetFITC at pH 7.4 for 10 min in BMECs. Means without a common letter or with a “*” differ, $P<0.05$. Values are the means \pm SEM ( $n=3$ per group).

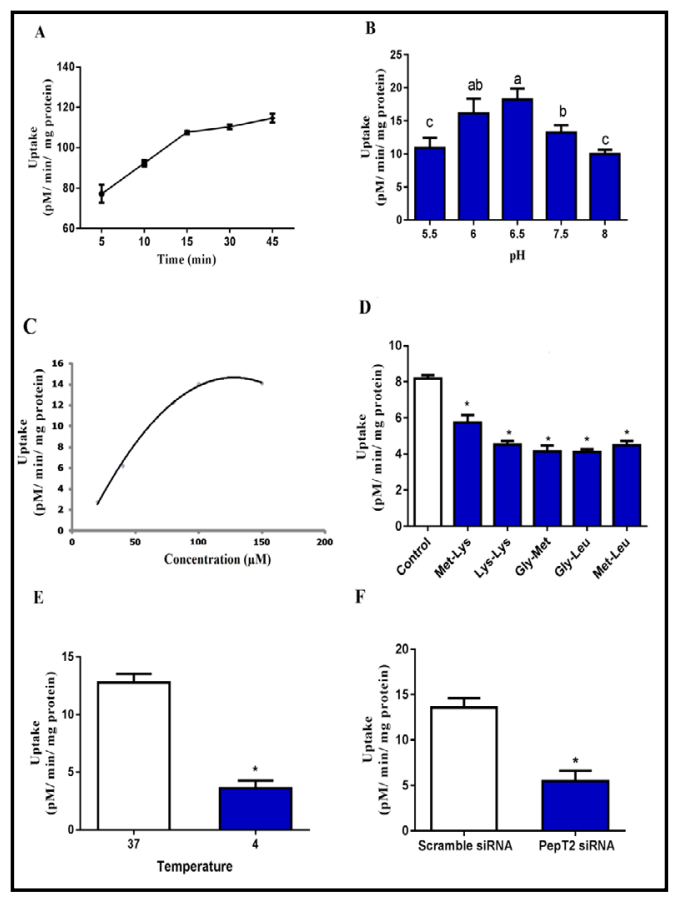

Fig. 2. Effects of methionyl-methionine (Met-Met) concentration $(0-160 \mu \mathrm{g} /$ $\mathrm{ml}$ ) on protein expression of PepT2 in bovine mammary epithelial cells. Upper panels: Western blot analysis of PepT2 and $\beta$-actin. Bottom panel: PepT2 levels in the upper panel were quantitatively scanned and normalized by $\beta$-actin levels. Means without a common letter differ, $P<0.05$. Values are the means \pm SEM $(n=3$ per group).

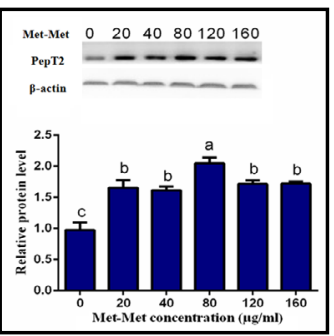

Fig. 3. Relative protein expression of $\beta$-casein $(\beta-\mathrm{CN})$ in bovine mammary epithelial cells under different concentrations of methionyl-methionine (MetMet, $(0-160 \mu \mathrm{g} / \mathrm{ml}))$. Upper panels: Western blot analysis of $\beta-\mathrm{CN}$. Bottom panel: $\beta$-actin and $\beta$-CN levels in the upper panel were quantitatively scanned and normalized by $\beta$-actin levels. Means without a common letter differ, $P<0.05$. Values are the means \pm SEM $(\mathrm{n}=3$ per group).

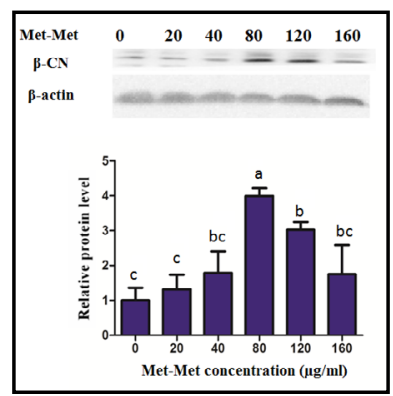

Met-Met increased PepT2 expression

Increasing extracellular concentrations of Met-Met from $20 \mu \mathrm{g} / \mathrm{ml}$ to $160 \mu \mathrm{g} / \mathrm{ml}$ concentration-dependently increased the expression of PepT2. The PepT2 expression was highest at $80 \mu \mathrm{g} / \mathrm{ml}$ of Met-Met (Fig. 2).

\section{Met-Met stimulated $\beta$-CN expression}

Treatment of BMECs with 80 and $120 \mu \mathrm{g} / \mathrm{ml}$ Met-Met significantly increased the expression of the $\beta$-CN expression in BMECs. The highest $\beta$-CN expression was at $80 \mu \mathrm{g} / \mathrm{ml}$ of Met-Met (Fig. 3). 
Met-Met enhanced cell proliferation

Treatment of BMECs with Met-Met concentration-dependently enhanced the cell viability (Fig. 4A) and cyclin D1 expression of BMECs (Fig. 4B). The highest cell viability and cyclin D1 expression was at 80 and $120 \mu \mathrm{g} / \mathrm{ml}$ of Met-Met. At the concentration of $80 \mu \mathrm{g} /$ $\mathrm{ml}$, Met-Met decreased cell numbers by $10.2 \%$ in the G0 phase and significantly increased the cell numbers in the $S$ and G1 phases compared with the control group cells receiving no Met-Met (Fig. 4C).

Met-Met increased the expression of JAK2 and STAT5 and phosphorylation of JAK2-STAT5 and $\mathrm{mTOR}$

The mRNA abundance of JAK2 and STAT5 was significantly increased when $80 \mu \mathrm{g} / \mathrm{ml}$ Met-Met was added (Fig. 5A). Treatment of BMECs with $80 \mu \mathrm{g} / \mathrm{ml}$ Met-Met significantly increased the phosphorylation of JAK2, STAT5, mTOR, S6K1 and 4EBP1 compared with the cells receiving no Met-Met control group (Fig. 5B).

Inhibition of JAK2 or mTOR decreased Met-Metstimulated cell viability and $\beta$-CN expression

The Met-Met-induced increases in cell viability and $\beta$-CN synthesis were significantly decreased after $100 \mathrm{ng} / \mathrm{ml}$ rapamycin was added (Fig. 6A and 6B). In addition, when $50 \mathrm{nM} \mathrm{AG-490}$ was added to inhibit JAK2 activity in BMECs, the MetMet-induced increases in cell viability and $\beta$-CN synthesis were also significantly decreased (Fig. 6C and 6D).

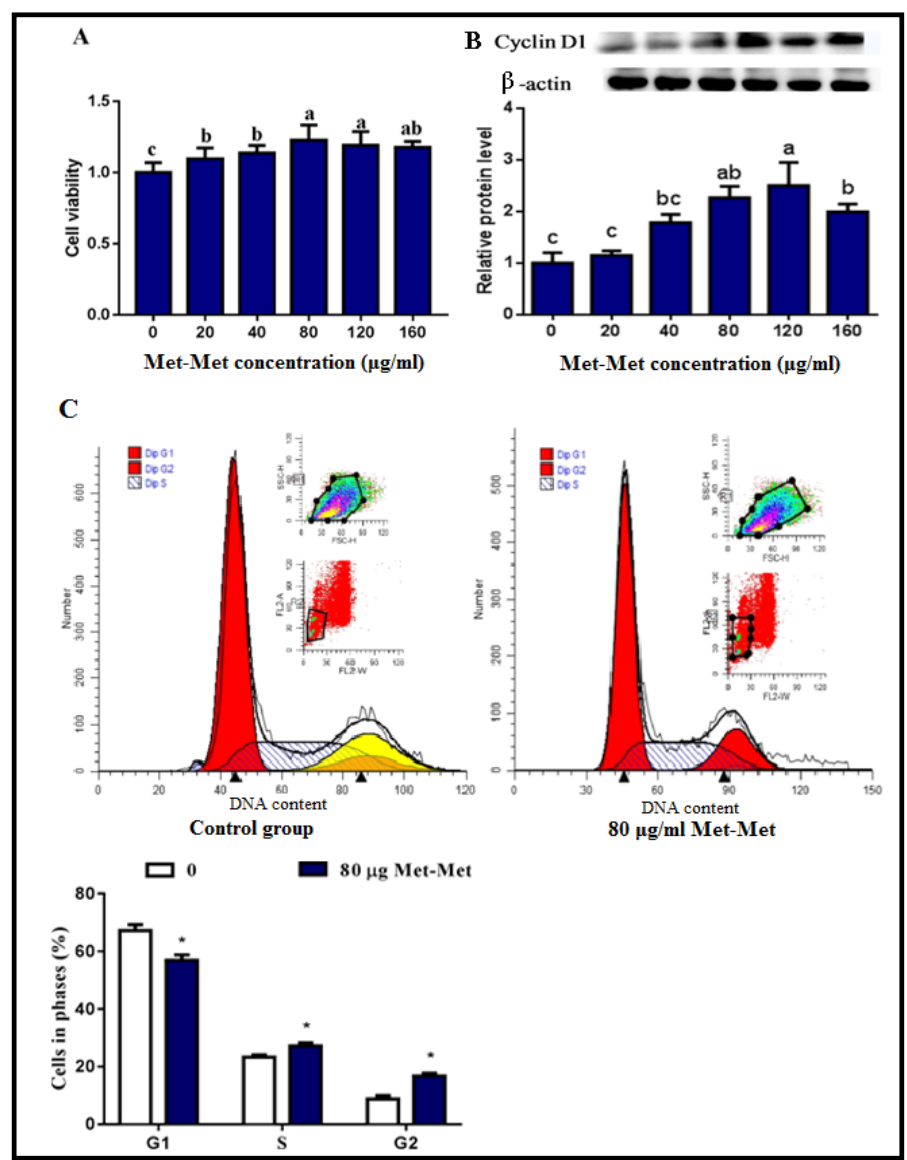

Fig. 4. Effects of methionyl-methionine (Met-Met) on cell proliferation in bovine mammary epithelial cells (BMECs). (A) Effects of methionyl-methionine (Met-Met) on cell viability in BMECs. (B) Relative protein expression of Cyclin D1 in BMECs under different concentrations of Met-Met. Upper panels: Western blot analysis of Cyclin D1. Bottom panel: $\beta$-actin and Cyclin D1 levels in the upper panel were quantitatively scanned and normalized by $\beta$-actin levels. (C) Addition of $80 \mu \mathrm{g} / \mathrm{ml}$ of Met-Met markedly decreased cell numbers in the G0 phase compared to the control group with no Met-Met in BMECs. Means without a common letter differ, $P<0.05$. Values are the means \pm SEM ( $n=3$ per group). 
Fig. 5. Effects of methionylmethionine (Met-Met) on JAK2STAT5 and mTOR signaling pathway in bovine mammary epithelial cells (BMECs). (A) Relative mRNA abundance of JAK2 and STAT5 in BMECs cultured with 0 and $80 \mu \mathrm{g} /$ ml of Met-Met. (B) Effects of Met-Met on phosphorylation of JAK2-STAT5 and mTOR signaling molecules. The upper panel is the Western blot analysis of JAK2-STAT5 and mTOR signaling molecules as well as their phosphorylated forms. The bottom panel is the

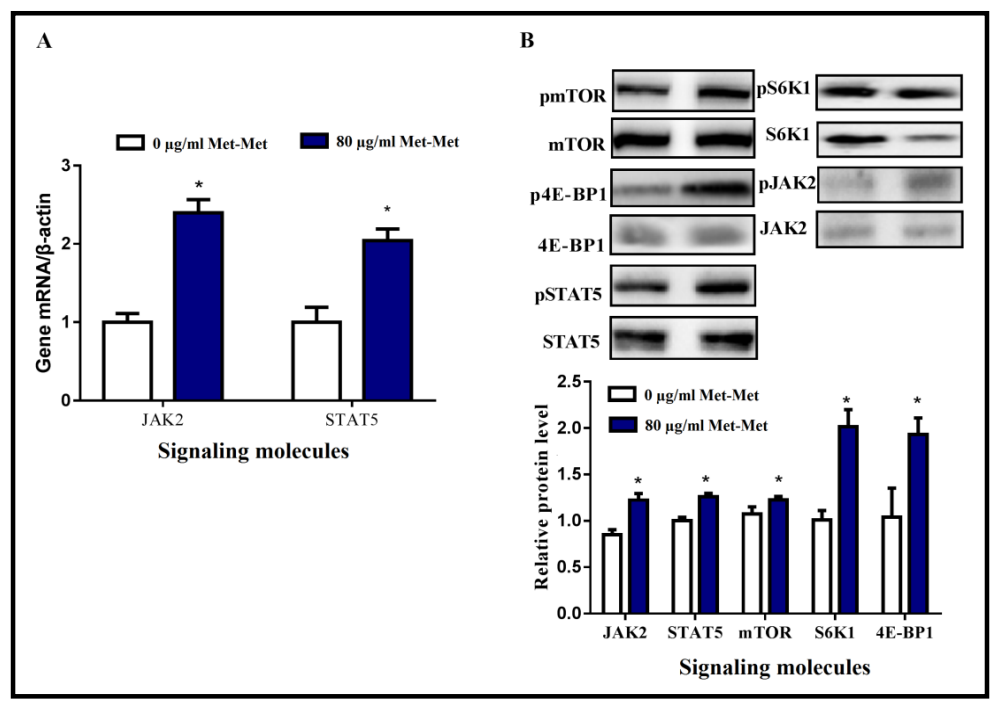
quantitative ratio between the phosphorylated form and the total protein of each molecule detected in the upper panel. Means without a common letter differ, $P<0.05$. Values are the means \pm SEM ( $n=3$ per group).

Fig. 6. Effects of rapamycin (100 ng/ml) and tyrphostin AG-490 $(50 \mu \mathrm{M})$ on Met-Metstimulated cell viability and $\beta$-casein $(\beta-C N)$ synthesis in bovine mammary epithelial cells cultured with or without $80 \mu \mathrm{g} / \mathrm{ml}$ of Met-Met. (A) Effects of rapamycin on MetMet-stimulated cell viability. (B) Effects of rapamycin on Met-Met-stimulated $\quad \beta$-CN synthesis. (C) Effects of AG490 on Met-Met-stimulated cell viability. (D) Effects of AG490 on Met-Met-stimulated $\beta-\mathrm{CN}$ synthesis. Means without a common letter differ, $P<0.05$. Values are the means \pm SEM ( $n=3$ per group).

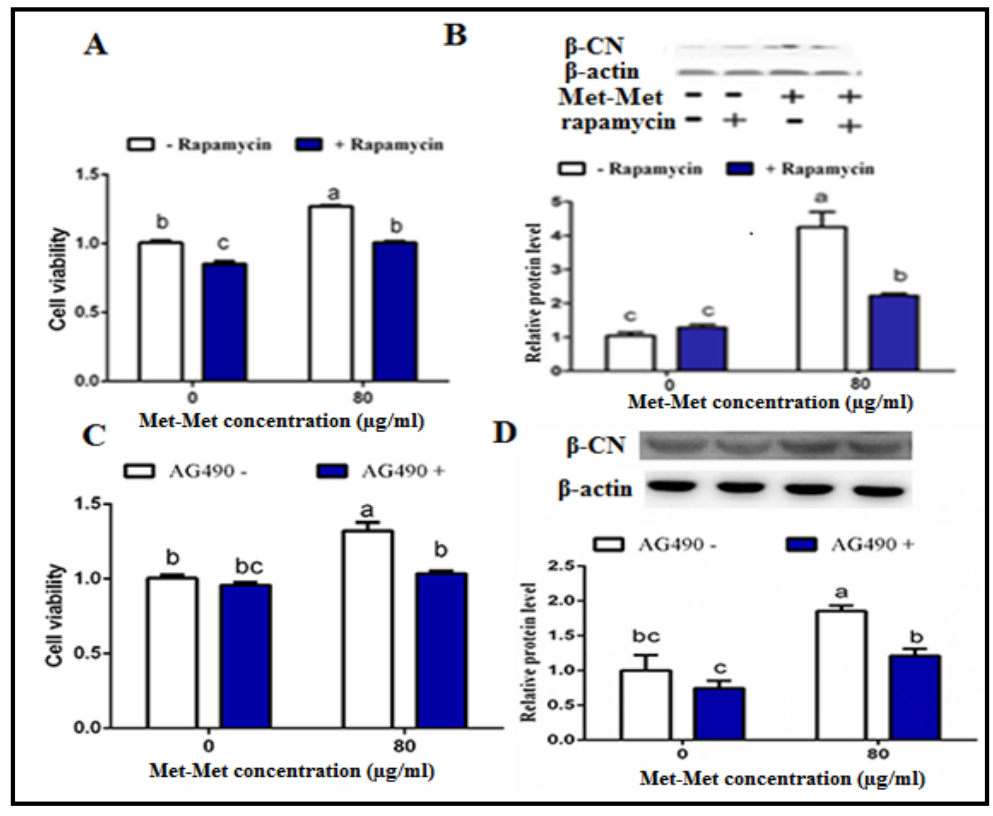

\section{Discussion}

Peptide transporters play a vital role in peptide absorption and utilization in the cells. Among the identified peptide transporters, only PepT2 was found to be expressed in bovine mammary gland [19]. PepT2, which was characterized as a high affinity and low capacity transporter, has been shown to have an important nutritional and physiological role in the absorption of di- and tripeptides, as well as peptidomimetic compounds, in cells via an inward proton gradient $[10,19]$. In this study, we used a fluorescence-labeled dipeptide MetMet-FITC to characterize the peptide transport kinetic properties in BMECs. Fluorescencebased methods have high sensitivity and are easy to assess with multiwell plate readers [20]. Several studies with fluorescent peptide transporter substrates have been reported [20-23]. 
Our results identified a linear range of peptide uptake in BMECs within the first 15 min of incubation with the substrate. The uptake was proton-dependent and the optimal $\mathrm{pH}$ for the uptake was 6.5, which is consistent with previous studies of human PepT2 in transfected Hela cells [24]. The Met-Met transport was fitted into Michaelis-Menten type kinetics, and the Km and Vmax values that we obtained were similar to previously reported values [75.5 $\mu \mathrm{M}(\mathrm{Km})$ and $25.4 \pm 2.1 \mathrm{pmol} / \mathrm{min}$ per mg protein (Vmax)] in mouse splenic macrophages for Ala-LysAMCA uptake [25]. The low Michaelis constant and high maximum transport velocity are consistent with the transport properties of the PepT2. The Met-Met uptake in BMECs can be inhibited by Met-Lys, Lys-Lys, Gly-Met, Gly-Leu and Met-Leu, indicating that these peptides are also substrates for the peptide transporters in BMECs. The uptake of Met-Met was higher at $37^{\circ} \mathrm{C}$ than at $4^{\circ} \mathrm{C}$, which indicated that the main route for Met-Met entering BMECs is through peptide transporters. The role of PepT2 in this process was supported by significant inhibition of Met-Met uptake by PepT2 siRNA and by enhanced protein expression of PepT2 by $80 \mu \mathrm{g} / \mathrm{ml}$ Met-Met. Taken together, our data support the possibility that PepT2 plays an important role in Met-Met uptake in BMECs.

PBAA has been reported to promote protein synthesis and secretion in different studies $[15,26]$. In the study, $80 \mu \mathrm{g} / \mathrm{ml}$ Met-Met significantly increased $\beta$-CN expression in BMECs. In our previous studies, substitution of $15 \%$ free Met by Met-Met significantly increased milk protein expression in bovine mammary explants [7]. Pan et al. (1997) revealed that methionine-containing di- to octapeptides can be used for both protein accumulation and cell proliferation in cultured ovine myogenic satellite cells [27]. Wang et al. (1996) showed that eleven of the seventeen methionine-containing peptides increased secreted protein synthesis by $15 \%-76 \%$ from free methionine in the lactating mice [6].

The cell number and cell viability in the mammary gland determines milk production [28]. Proliferation of mammary epithelial cells can be influenced by amino acids [29]. A previous study revealed that Lys, Met and mixtures of Lys and Met enhanced the cell proliferation of BMECs [29]. In this study, our results showed that proliferation of BMECs was dependent on the concentrations of supplemental Met-Met. The concentration of 80 $\mu \mathrm{g} / \mathrm{ml}$ Met-Met resulted in greater cell proliferation and cell viability compared with the no Met-Met control cells. The cell cycle is a precisely regulated process that contains G1, S, G2 and $\mathrm{M}$ phases [30]. The cell cycle slows during the G0/G1 phase and progression to $\mathrm{S}$ phase does not occur until DNA is properly encoded. Cyclin D1 is a major factor that regulates cell proliferation in the cell cycle and promotes cell transition from Go phase to S phase [30]. In the study, Met-Met addition resulted in greater cyclin D1 expression. The viability of BMECs was significantly increased in the group of $80 \mu \mathrm{g} / \mathrm{ml}$ Met-Met. Moreover, $80 \mu \mathrm{g} / \mathrm{ml}$ Met-Met promoted cell cycle transition in the flow cytometry analysis. These results suggested that Met-Met may promote cell proliferation in the mammary gland and thus stimulate milk protein synthesis in vivo.

Met-Met could enhance $\beta$-CN expression through transcriptional and posttranscriptional regulation. The JAK2-STAT5 signaling functions in milk protein gene transcription, while mTOR signaling pathway and its downstream substrates, S6K1 and 4EBP1, play a great role in the translation of milk protein [31-33]. Previous studies revealed that AAs can activate mTOR signaling pathway to regulate $\beta$-CN synthesis $[13,29]$. The mTOR is a highly conserved serine/threonine protein kinase that controls cell growth and protein synthesis and can regulate mRNA binding to the $43 \mathrm{~S}$ initiation complex by influencing the phosphorylation of 4EBP1 [13]. The phosphorylation of 4EBP1 releases the eIF4E and results in cap-dependent translation [33]. In the present study, $80 \mu \mathrm{g} / \mathrm{ml}$ Met-Met significantly increased the mRNA abundance of JAK2 and STAT5 and enhanced the phosphorylation of JAK2, STAT5, mTOR, 4EBP1 and S6K1, which corresponds to the upregulation of $\beta$-CN. This result indicates that Met-Met may regulate $\beta$-CN synthesis through JAK2-STAT5 and mTOR signaling pathway. To further investigate whether JAK2-STAT5 and mTOR are involved in Met-Met stimulated cell growth and $\beta$-CN synthesis in BMECs, AG-490 and rapamycin were used to inhibit JAK2 and mTOR activity, respectively. The results showed that both AG-490 and rapamycin decreased Met-Met-stimulated cell viability and $\beta$-CN synthesis. Together, our results indicated that

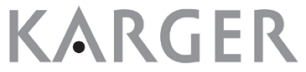




\section{Cellular Physiology Cell Physiol Biochem 2018:49:479-488 \begin{tabular}{l|l|l} 
and Biochemistry & $\begin{array}{l}\text { DOI: 10.1159/000492987 } \\
\text { Published } 2018 \text { The Author(s). Published by S. Karger AG, Basel }\end{array}$ \\
\hline www.karger.com/cpb
\end{tabular}}

Wang et al.: Dipeptide Transport and Its Effect on $\beta$-Casein Synthesis

Met-Met-induced increase of $\beta$-CN synthesis is mediated via the JAK2-STAT5 and mTOR signaling pathways.

\section{Conclusion}

We characterized the transport kinetics and substrate specificities of peptide transporter (likely PepT2) in BMECs. In addition, we observed that Met-Met, taken up by PepT2, enhanced cell proliferation and promoted $\beta$-CN synthesis by activating the JAK2-STAT5 and mTOR signaling pathways in BMECs.

\section{Acknowledgements}

This work was supported in part by the grants from the Funds for Distinguished Young Scientists of Zhejiang Province (LR16C170002), the Fundamental Research Funds for the Central Universities (2017FZA6017) and the National Natural Science Foundation of China (No. 31372336).

\section{Disclosure Statement}

The authors have no competing financial interests to declare.

\section{References}

$\longrightarrow 1$ Metcalf JA, Wray-Cahen D, Chettle EE, Sutton JD, Beever DE, Crompton LA, Macrae JC, Bequette BJ, Backwell FR: The effect of dietary crude protein as protected soybean meal on mammary metabolism in the lactating dairy cow. J Dairy Sci 1996;79:603-611.

-2 Bequette BJ, Backwell FR, Kyle CE, Calder AG, Buchan V, Crompton LA, France J, Macrae JC: Vascular sources of phenylalanine, tyrosine, lysine, and methionine for casein synthesis in lactating goats. J Dairy Sci 1999;82:362-377.

3 Mabjeesh SJ, Kyle CE, Macrae JC, Hanigan MD, Bequette BJ: Vascular sources of amino acids for milk protein synthesis in goats at two stages of lactation. J Dairy Sci 2002;85:919-929.

4 Seal CJ, Parker DS: Isolation and characterization of circulating low molecular weight peptides in steer, sheep and rat portal and peripheral blood. Com Biochem Phys B 1991;99:679-685.

5 Pan Y, Bender PK, Akers RM, Webb KE Jr: Methionine-containing peptides can be used as methionine sources for protein accretion in cultured C2C12 and MAC-T cells. J Nutr 1996;126:232-241.

6 Wang S, Webb KE Jr, Akers MR: Peptide-bound methionine can be a source of methionine for the synthesis of secreted proteins by mammary tissue explants from lactating mice. J Nutr 1996;126:1662-1672.

7 Yang JX, Wang CH, Xu QB, Zhao FQ Liu JX, Liu HY: Methionyl-methionine promotes a-s1 casein synthesis in bovine mammary gland explants by enhancing intracellular substrate availability and activating JAK2STAT5 and mTOR-mediated signaling pathways. J Nutr 2015;145:1748-1753.

-8 Smith DE, Johanson CE, Keep RF: Peptide and peptide analog transport systems at the blood-CSF barrier. Adv Drug Deliver Rev 2004;56:1765-1791.

-9 Boll M, Herget M, Wagener M, Weber WM, Markovich D, Biber J, Clauss W, Murer H, Daniel H: Expression cloning and functional characterization of the kidney cortex high-affinity proton-coupled peptide transporter. P Natl Acad Sci USA 1996;93:284-289.

10 Newstead S: Recent advances in understanding proton coupled peptide transport via the POT family. Curr Opin Struct Biol 2017;45:17-24.

11 Xu QB, Fan HB, Yu WL, Hong H, Wu JP: Transport study of egg-derived antihypertensive peptides (LKP and IQW) using caco-2 and ht29 coculture monolayers. J Agr Food Chem 2017;65:7406-7414. 


\section{Cellular Physiology Cell Physiol Biochem 2018;49:479-488 \begin{tabular}{l|l} 
DOI: 10.1159/000492987 & $\begin{array}{l}\text { O } 2018 \text { The Author(s). Published by S. Karger AG, Basel } \\
\text { www.karger.com/cpb }\end{array}$
\end{tabular}

12 Corradetti MN, Guan KL: Upstream of the mammalian target of rapamycin: do all roads pass through mTOR? Oncogene 2006;25:6347-6360.

-13 Goberdhan DCI, Boyd CA: mTOR: dissecting regulation and mechanism of action to understand human disease. Biochem Soc T 2009;37:213-216.

14 Appuhamy JA, Knoebel NA, Nayananjalie WA, Escobar J, Hanigan MD: Isoleucine and leucine independently regulate mTOR signaling and protein synthesis in MAC-T cells and bovine mammary tissue slices. J Nutr 2012;142:484-491.

15 Zhou MM, Wu YM, Liu HY, Liu JX: Effects of phenylalanine and threonine oligopeptides on milk protein synthesis in cultured bovine mammary epithelial cells. J Anim Physiol An N 2015;99:215-220.

-16 Zhao K, Liu HY, Zhou MM, Zhao FQ, Liu JX: Protein kinase C regulates glucose uptake and mRNA expression of GLUT1 and GLUT8 in lactating bovine mammary epithelial cells. J Dairy Sci 2014;97:4329-4332.

$>17$ Liu HY, Zhao K, Zhou MM, Wang C, Ye JA, Liu JX: Cytoprotection of vitamin E on hyperthermia-induced damage in bovine mammary epithelial cells. J Therm Biol 2010;35:250-253.

18 Yang XD, Ma JY, Barger MW, Ma JK: Transport and utilization of arginine and arginine-containing peptides by rat alveolar macrophages. Pharm Res 2002;19:825-831.

19 Zhou MM, Wu YM, Liu HY, Zhao K, Liu JX: Effects of tripeptides and lactogenic hormones on oligopeptide transporter 2 in bovine mammary gland. J Anim Physiol Anim Nutr 2011;95:781-789.

20 Landowski CP, Han KD, Lee KD, Amidon GL: A fluorescent hPept1 transporter substrate for uptake screening. Pharm Res 2003;20:1738-1745.

21 Kottra G, Spanier B, Verri T, Daniel H: Peptide transporter isoforms are discriminated by the fluorophoreconjugated dipeptides $\beta$-ala-and d-ala-lys-n-7-amino-4-methylcoumarin-3-acetic acid. Physiol Rep 2013;1:e00165.

22 Tai W, Chen Z, Cheng K: Expression profile and functional activity of peptide transporters in prostate cancer cells. Mol Pharm 2013;10:477-487.

-23 Agu R, Cowley E, Shao D, Macdonald C, Kirkpatrick D, Renton K, Massoud E: Proton-coupled oligopeptide transporter (POT) family expression in human nasal epithelium and their drug transport potential. Mol Pharm 2011;8:664-672.

24 Guo XJ, Meng Q, Liu Q, Wang CY, Sun HJ, Kaku T, Liu KX: Construction, identification and application of HeLa cells stably transfected with human PEPT1 and PEPT2. Peptides 2012;34:395-403.

25 Sun DL, Wang YQ Tan FQ Fang DB, Hu YJ, Smith DE, Jiang HD: Functional and molecular expression of the proton-coupled oligopeptide transporters in spleen and macrophages from mouse and human. Mol Pharm 2013;10:1409-1416.

26 Tagari H, Jr KW, Theurer B, Huber T, Deyoung D, Cuneo P, Santos JEP, Simas J, Sadik M, Alio A, Lozano O, Delgado-Elorduy A, Nussio L, Bittar CMM, Santos F: Mammary uptake, portal-drained visceral flux, and hepatic metabolism of free and peptide-bound amino acids in cows fed steam-flaked or dry-rolled sorghum grain diets. J Dairy Sci 2008;91:679-697.

-27 Pan Y, Webb KE Jr: Peptide-bound methionine as methionine sources for protein accretion and cell proliferation in primary cultures of ovine skeletal muscle. J Nutr 1998;128:251-256.

-28 Boutinaud M, Guinardflamenta J, Jammes H: The number and activity of mammary epithelial cells, determining factors for milk production. Reprod Nutr Dev 2004;44:499-508.

29 Nan XM, Bu DP, Li XY, Wang JQ Wei HY, Hu H, Zhou LY, Juan LL: Ratio of lysine to methionine alters expression of genes involved in milk protein transcription and translation and mTOR phosphorylation in bovine mammary cells. Physiol Genomics 2014;46:268-275.

-30 Johnson DG, Walker CL: Cyclins and cell cycle checkpoints. Annu Rev Pharmacol 1999;39:295-312.

31 Massimo B, Loor JJ: Gene networks driving bovine mammary protein synthesis during the lactation cycle. Bioinform Biol Insights 2011;5:83-98.

-32 Weinstein SL, Finn AJ, Dave SH, Meng F, Lowell CA, Sanghera JS, DeFranco AL: Phosphatidylinositol 3-kinase and mTOR mediate lipopolysaccharide-stimulated nitric oxide production in macrophages via interferonbeta. J Leukoc Biol 2000;67:405-414.

-33 Gingras AC, Raught B, Sonenberg N: Regulation of translation initiation by FRAP/mTOR. Gene Dev 2001;15:807-826. 